\title{
PERFORMANCE AND HISTOMORPHOLOGICAL PARAMETERS OF BROILER CHICKS FED LOW CRUDE PROTEIN DIET SUPPLEMENTED WITH MORINGA OLEIFERA LEAVES POWDER
}

\author{
Manal K. Abou El - Naga, A. M. H. Abou - Ashour, S.A.A. Abd El-Rahman, \\ and M. Gh. Abou Abed \\ Poult. And Fish Prod. Dept, Fac. of Agric., Menoufia Univ., Shebin El-Kom, Egypt.
}

Received: Jun. 2, 2020

Accepted: Sep. 30,2020

\begin{abstract}
The present experiment was conducted in order to investigate the effect of Moringa Oleifera Leaves powder on the performance, some blood serum components, some histomorphological measurements and economic efficiency of broiler chickens. A total of 225 Cobb unsexed one - day old broiler chicks, were distributed at random into 5 treatments each in 3 replicates, 15 chicks each. Moringa Oleifera leaves powder (MOL) was added at the levels of $0,0.25,0.50$ and $0.75 \%$ to low crud protein diet (LCP, 20 and $17 \%$, negative control) compared to the normal crud protein ( 23 and $20 \%$, positive control), respectively at the starter (1- $21 \mathrm{~d})$ and at the finisher (22-35d) period.
\end{abstract}

Results indicated that, chicks fed the low crude protein diet supplemented with Moringa Oliefera leaves powder (MOL) had significantly ( $P \leq 0.05)$ higher body weight, body weight gain, daily feed intake and performance index. Feed conversion ratio, European efficiency index and relative economic efficiency were also improved with the supplementation. Chicks fed low crude protein diet supplemented with 0.25 or $0.50 \%$ MOL have the highest dressing weight (1753 and $1738 \mathrm{~g}$ ) with no significant differences between them compared and increased serum total protein and glucose levels, while significantly decreased serum total cholesterol and aspartic transaminase (AST) enzyme compared to the other treatments with increasing the levels of MOL up to $0.50 \%$. Morphological sections of small intestine revealed that villi height, width and height: width ratios were increased by the supplementation of different levels of MOLM ( 0.25 and $0.50 \%$ ) but not significant except in duodenum villi width and in the ration between height and width.

In general, the obtained results indicated that supplementation of $0.25 \%$ Moringa Oliefera Leaves, MOL can be used in broiler diets with low protein level to get the heaviest weight, best feed conversion, performance index, due to an increase in small intestinal absorption and activity. This, in turn, resulted in an increase in European efficiency index and economic efficiency under the experimental conditions.

Key words: Moringa Oliefera Leaves powder, low crude protein, broilers, growth, carcass, serum components, histomorphological parameters and diet.

\section{INTRODUCTION}

Broiler production supplies the populations with animal proteins, but it is highly constrained by the availability, quality and cost of feed ingredients regardless of the system of production (Ugwuowo et al. 2019). Poultry plays very important role for mankind through food supply, income and employment generation, providing raw materials to some industries. Food and Agriculture Organization FAO (2010) reported that broiler chicken farm business has grown into a complete industry with rapid development due to the increasing and rapid demand for chicken meat especially when meat products from other farm animals have high retail prices. 
In developing countries, the poultry production sectors are facing some problems, such as increased food costs; due to this, alternative sources have been sought in their diet that is available and not expensive. Poultry farming has a high impact in the economic and social spheres; since more than $60 \%$ of the animal protein consumed in the world comes from the poultry industry (Sagarpa, 2017). In Egypt poultry production sectors are facing some problems, one of which is the cost of feed due to high prices of protein and energy sources (Abbas, 2013). Feed cost accounts for 60 to $70 \%$ of the total cost of poultry production. The high cost of conventional feed ingredients in poultry diets has necessitated the investigation into un-conventional readily available feed stuffs. The impact of indigenous chickens in improving the nutritional status, income, food security and livelihood of small holders is significant owing to their low cost of production (FAO, 1997).

However, the recent hike in the prices of conventional feed ingredients is a major factor affecting net return on investment from the poultry business. This has compelled animal nutritionists to explore the incorporation of nonconventional feed stuffs in poultry diets. Any attempt to improve commercial poultry production and increase its efficiency therefore needs to focus on searching for alternative and better utilization of feed resources (Udedibie and Asoluka , 2008). However, the recent hike in the prices of conventional feed ingredients is a major factor affecting net return on investment from the poultry business. This has compelled animal nutritionists to explore the incorporation of non-conventional feed stuffs in poultry diets. Any attempt to improve commercial poultry production and increase its efficiency therefore needs to focus on searching for alternative and better utilization of feed resources (Udedibie and Asoluka, 2008).

In addition, researchers are searching for cheap, available, and safe alternative sources of protein and energy (Abbas, 2013). Scientists are also looking for natural antimicrobial ingredients, some legumes and tropical into poultry meals as an ingredient or addition to broiler chickens as a source to reduce feed costs and improve performance in broiler birds.

Moringa Oleifera is a tree with many uses and of great economic importance. It was incorporated into the poultry diet by nutritionists to examine its effects on broilers birds' productive performance. Moringa Oleifera leaves have the potential to supply some needed nutrients for the growth of broilers and reduce the cost of supplementary synthetic nutrients (Esiegwu, 2019). Nihad et al. (2016) reported the proximate composition of Moringa Oleifera to contain $5.89 \%$ ash, $17.41 \%$ fiber, $25.37 \%$ protein, $2.44 \%$ lipid and $39.02 \%$ total sugars and similarly Sodamade et al., (2013) reported that the proximate and mineral composition of Moringa Oleifera leaves contained $6.00 \%$ ash, $2.43 \%$ crude fat, $5.43 \%$ crude fiber, $39.13 \%$ crude protein, $\quad 38.21 \% \quad$ carbohydrate, $23.20 \mathrm{mg} / 100 \mathrm{~g} \mathrm{~K}, 214.00 \mathrm{mg} / 100 \mathrm{~g} \mathrm{Na}, 723$ $\mathrm{mg} / 100 \mathrm{~g} \mathrm{Ca}, 677.00 \mathrm{mg} / 100 \mathrm{~g} \mathrm{Mg}, 5.00$ $\mathrm{mg} / 100 \mathrm{~g} \mathrm{P}, 187 \mathrm{mg} / 100 \mathrm{~g} \mathrm{Fe}, 252 \mathrm{mg} / 100 \mathrm{~g}$ $\mathrm{Mn}, 55 \mathrm{mg} / 100 \mathrm{~g} \mathrm{Cu}$ and $548 \mathrm{mg} / 100 \mathrm{~g}$ of $\mathrm{Zn}$. The values reported is an indication that Moringa Oleifera leaves are nutritionally rich and could serve as supplements in broiler diets.

Therefore, the aim of this study was to assess the benefits of Moringa Oliefera leaves as a feed additive in broiler chickens in terms of growth performance, feed consumption, carcass characteristics, some serum blood parameters and some intestinal morphology of Cobb chicks. 


\section{MATERIALS AND METHODS}

The present study was conducted at a private farm in Sadat City, Menoufia governorate, Egypt, throughout the experimental period from October to November 2018 in order to investigate the effect of some herbal feed additives on the performance, some blood serum biochemical parameters and some histomorphological measurements of broiler chickens.

\section{a. Birds, housing and feeding:}

Two hundred and twenty five, one day old broiler chicks (Cobb) were randomly assigned to five treatments, reared under similar management and hygienic conditions. Feed and water were provided ad-libitum during the experimental period (35 days). Artificial light was used to provide 24 hour photo period. Chicks were individually weighed, wing - banded and randomly assigned to five treatment $\left(T_{1}, T_{2}, T_{3}, T_{4}\right.$ and $\left.T_{5}\right)$ groups nearly similar in average body weight, (3 replicates pens of 15 chick each, $\sim 40 \mathrm{~g})$. Moringa Oliefera leaves powder was added at the levels of 0 , $0.25,0.50$ and $0.75 \%$ to the low crud protein (LCP) diet (20 and 17\%, negative control) compared to the normal crud protein (23 and 20\%, positive control), respectively at the starter (1- $21 \mathrm{~d}$ ) and at the finisher (22- 35d) period. Birds received their diets to save the nutrient requirements according to the NRC (1994, Tables 1 and 2).

\section{b. Growth performance parameters:}

Body weight (BW), body weight gain (BWG), feed intake (FI) and mortality were recorded weekly. Feed conversion ratio (FCR, g feed Ig gain) was calculated every week during the experimental period. Performance index (PI) was calculated according to North (1981). Where: $\mathrm{PI}=$ live body weight, $\mathrm{kg} \times 100 \mathrm{I}$ feed conversion.

$$
\mathrm{PI}=\frac{\text { live body weight } \mathrm{kg}}{\text { feed conversion }} * 100
$$

European efficiency index (EEI) was calculated also cited by Soltan and Kusainova (2012).

Where: EEI = (Mean BW, kg × Livability, $\%)$ I (Marketing age, days $x$ FCR) $\times 100$.

EEI $=\frac{\text { Mean BW } \mathrm{Bg}_{\mathrm{g}} \times \text { Livability }{ } \%}{\text { Marketing age } \text { days } \times \mathrm{FCR}_{2} a} * 100$

\section{c. Carcass traits and histomorphological samples:}

At the end of the experiment (5 weeks of age), 3 birds from each treatment around the average live body weight were randomly chosen, fasted for about 12 hours, weighed and slaughtered to complete bleeding, followed by plucking the feathers. Carcass without giblets and some giblets (liver, heart and gizzard) weights were calculated relative to live body weight as following:

Dressing \% = Carcass weight $(g) \times 100 I$ Live body weight $(g)$.

Dressed carcass $\%=\frac{\text { Eveserated carcass weight }}{\text { Live body weight }} * 100$

The small intestines of chicks were removed immediately, after slaughtering and segments of approximately $2 \mathrm{~cm}$ was taken from duodenum, jejunum and ileum at 35 day age for histological analysis. Segments referred to the midpoint of the duodenum (from gizzard to pancreobiliary duct, duodenum), jejunum (the midpoint between the entry of the common bile duct and the Meckel's diverticulum), and ileum (from Meckel's diverticulum to ileocecal junction). Particular segments was gently flushed and rinsed with $0.9 \%$ physiological saline and then fixed in a $4 \%$ neutral-buffered formalin solution for histological study.

Intestinal samples were transferred from formaldehyde after dehydration by passing tissue through a series of 
alcohol solutions, were cleared by xylene and were embedded in paraffin. All samples were sectioned at $5-\mu \mathrm{m}$ thickness using a rotary microtome. Sections were sequentially transferred to glass slides and stained with Hematoxylin and Eosin ( $H$ and E). After being dried, sections were analyzed under a light microscope. Morphometric measurements were performed on 9 villi chosen from each sample. The height of intestinal villi was measured from the tip to the base of villi at the opening crypt, and the villus width was measured at its midpoint (Geyra et al., 2001).

Table 1. Composition and calculated analysis of the positive and negative control diets fed during starting period (1- 21d).

\begin{tabular}{|c|c|c|c|c|c|}
\hline \multirow{2}{*}{ Ingredients } & \multirow{2}{*}{$\begin{array}{c}\text { Positive } \\
\text { control } \\
\text { diets, } T_{1}\end{array}$} & \multirow{2}{*}{$\begin{array}{c}\text { Negative } \\
\text { control } \\
\text { diets, } T_{2}\end{array}$} & \multicolumn{3}{|c|}{ Moringa Oliefera Leaves levels, \% } \\
\hline & & & $\begin{array}{c}0.25, \\
T_{3}\end{array}$ & $\begin{array}{c}0.50 \\
\mathrm{~T}_{4}\end{array}$ & $\begin{array}{c}0.75 \\
T_{5}\end{array}$ \\
\hline Yellow corn, $8.5 \%$. & 48.5 & 57.13 & 59.4 & 59.2 & 59.2 \\
\hline Soybean meal, 44\%. & 39.60 & 33.75 & 30.73 & 30.73 & 30.73 \\
\hline Corn gluten, $60 \%$. & 2.25 & 0.5 & 2.1 & 2.05 & 2 \\
\hline Vegetable oil. & 5.70 & 4.82 & 4.00 & 4.00 & 4.00 \\
\hline MOLㄴ. & -- & 0.00 & 0.25 & 0.50 & 0.75 \\
\hline $\begin{array}{l}\text { Di-calcium } \\
\text { phosphate. }\end{array}$ & 1.50 & 1.75 & 1.55 & 1.55 & 1.55 \\
\hline Limestone. & 1.65 & 1.45 & 1.65 & 1.65 & 1.65 \\
\hline $\begin{array}{l}\text { Vitamins and } \\
\text { minerals mixture }{ }^{2} \text {. }\end{array}$ & 0.30 & 0.30 & 0.30 & 0.30 & 0.30 \\
\hline Salt. & 0.30 & 0.30 & 0.30 & 0.30 & 0.30 \\
\hline Methionine ${ }^{3}$. & 0.20 & -- & 0.20 & 0.20 & 0.20 \\
\hline Total & 100 & 100 & 100 & 100 & 100 \\
\hline \multicolumn{6}{|c|}{ Calculated analysis ( air dry basis) ${ }^{4}:$} \\
\hline Crude protein, $\%$. & 23 & 20 & 20 & 20.01 & 20.05 \\
\hline ME, kcal/kg diet. & 3096 & 3108 & 3101 & 3102 & 3100 \\
\hline C/P ratio. & 134 & 155 & 155 & 155 & 154 \\
\hline Ca. & 1.05 & 1.01 & 1.04 & 1.04 & 1.06 \\
\hline Av. P. & 0.46 & 0.46 & 0.46 & 0.46 & 0.46 \\
\hline
\end{tabular}

${ }^{1}$ Proximate composition of Moringa Oliefera leaves was cited by Esiegwu, 2019.

${ }^{2}$ Vitamins and minerals mixture at $\mathbf{0 . 3 0} \%$ of the diet supplies the following/ $\mathrm{kg}$ of the diet: Vit. A, 12000 IU; Vit. $D_{3}, 2500$ IU; Vit. E, 10 mg; Vit. K3, 3 mg; Vit $B_{1}, 1$ mg; Vit. B2, 4 mg; Pantothenic acid, $10 \mathrm{mg}$;Nicotinic acid, 20 mg; Folic acid, $1 \mathrm{mg}$; Biotin, $0.05 \mathrm{mg}$; Niacin, 40 mg; Vit.B6, 3 mg; Vit B 12, $0.02 \mathrm{mg}$; Choline chloride, $400 \mathrm{mg}$; Mn, $62 \mathrm{mg}$; Fe, $44 \mathrm{mg}$; Zn, 56 mg; I, 1 mg; Cu, 5 mg and Se, $0.01 \mathrm{mg}$.

${ }^{2} \mathrm{DL}$ - Methionine: $98 \%$ feed grade (98 \% Methionine).

${ }^{4}$ Calculated according to NRC (1994). 
Table 2. Composition and calculated analysis of the positive and negative control diets fed during finishing period (22-35d).

\begin{tabular}{|c|c|c|c|c|c|}
\hline \multirow{2}{*}{ Ingredients } & \multirow{2}{*}{$\begin{array}{c}\text { Positive } \\
\text { control } \\
\text { diets, } T_{1}\end{array}$} & \multirow{2}{*}{$\begin{array}{c}\text { Negative } \\
\text { control } \\
\text { diets, } T_{2}\end{array}$} & \multicolumn{3}{|c|}{ Moringa Oliefera Leaves levels, \% } \\
\hline & & & $\begin{array}{c}0.25 \\
\mathrm{~T}_{3}\end{array}$ & $\begin{array}{c}0.50 \\
\mathrm{~T}_{4}\end{array}$ & $\begin{array}{c}0.75 \\
T_{5}\end{array}$ \\
\hline Yellow corn, $8.5 \%$. & 56.96 & 67.8 & 66.22 & 66.03 & 65.93 \\
\hline Soybean meal, $44 \%$. & 34.50 & 25.55 & 25.5 & 25.45 & 25.3 \\
\hline Corn gluten, $60 \%$. & --- & -- & --- & --- & -- \\
\hline Vegetable oil. & 4.77 & 2.80 & 3.80 & 3.78 & 3.78 \\
\hline MOLM ${ }^{1}$. & --- & 0.00 & 0.25 & 0.50 & 0.75 \\
\hline $\begin{array}{l}\text { Di-calcium } \\
\text { phosphate. }\end{array}$ & 1.75 & 1.75 & 1.95 & 1.95 & 1.95 \\
\hline Limestone. & 1.42 & 1.50 & 1.40 & 1.40 & 1.40 \\
\hline $\begin{array}{l}\text { Vitamins and } \\
\text { minerals mixture }{ }^{2} .\end{array}$ & 0.30 & 0.30 & 0.30 & 0.30 & 0.30 \\
\hline Salt. & 0.30 & 0.30 & 0.30 & 0.30 & 0.30 \\
\hline Methionine ${ }^{3}$. & --- & -- & 0.20 & 0.20 & 0.20 \\
\hline Total & 100 & 100 & 100 & 100 & 100 \\
\hline \multicolumn{6}{|c|}{ Calculated analysis (air dry basis)4: } \\
\hline Crude protein,\%. & 20.02 & 17 & 17.01 & 17.03 & 17.03 \\
\hline ME, kcal/kg diet. & 3098 & 3091 & 3128 & 3132 & 3131 \\
\hline C/P ratio. & 154 & 181 & 183 & 183 & 183 \\
\hline Ca. & 1.00 & 1.01 & 1.02 & 1.02 & 1.02 \\
\hline Av. P. & 0.46 & 0.46 & 0.46 & 0.46 & 0.46 \\
\hline
\end{tabular}

${ }^{1}$ Proximate composition of Moringa Oleifera leaves was cited by Esiegwu, 2019.

${ }^{2}$ Vitamins and minerals mixture at $\mathbf{0 . 3 0} \%$ of the diet supplies the following/ $\mathbf{k g}$ of the diet: Vit. A, 12000 IU; Vit. $D_{3}, 2500 \mathrm{IU}$; Vit. E, 10 mg; Vit. K3, 3 mg; Vit $B_{1}, 1$ mg; Vit. $B_{2}, 4$ mg; Pantothenic acid, $10 \mathrm{mg}$;Nicotinic acid, 20 mg; Folic acid, $1 \mathrm{mg}$; Biotin, $0.05 \mathrm{mg}$; Niacin, 40 mg; Vit.B 6 , 3 mg; Vit B 12, $0.02 \mathrm{mg}$; Choline chloride, $400 \mathrm{mg}$; Mn, $62 \mathrm{mg}$; Fe, $44 \mathrm{mg}$; Zn, 56 mg; I, 1 mg; Cu, 5 mg and Se, $0.01 \mathrm{mg}$.

${ }^{2} \mathrm{DL}$ - Methionine: $98 \%$ feed grade (98\% Methionine).

${ }^{4}$ Calculated according to NRC (1994).

\section{d. Serum samples and} biochemistry:

Individual blood samples were collected from the same slaughtered birds for each dietary treatment into tubes without heparin and separated by centrifugation at $3000 \mathrm{rpm}$ for 15 minutes and frozen at -20 -C until analysis. Serum total protein, triglyceride, lipids, cholesterol, createnine, glucose and albumin were determined using commercial kits. Also, liver enzymes including aspartate transaminase (AST) and alanine transaminase (ALT) were calorimetrically estimated.

\section{e. Economic efficiency:}

The economic efficiency of the experimental diets used in the present study was calculated from the input - 
output analysis (Heady and Jensen, 1954), assuming that the other head costs were constant.

\section{f. Statistical analysis:}

Data were statistically analyzed by the completely randomized design using SPSS (2011) program and the differences among means were determined using Duncan's multiple range test (Duncan, 1955). Percentages were transformed to the corresponding arcsine values before performing statistical analysis (Snedecor and Cochran, 1982).

The model applied was:

$Y_{i j}=\mu+\alpha_{i}+E_{i j}$, Where:- $Y_{i j}=$ an observation. $\mu=$ Overall mean. $\alpha i=$ effect of treatment $(I=1,2,3,4, \ldots . .8)$, and $E_{i j}=$ Random error.

\section{RESULTS AND DISCUSSION}

1. Effect of dietary low crude protein diet supplemented with different levels of Moringa Oliefera Leaves meal (MOL) on Cobb chicks performance:

\section{a. Body weight and body weight gain:}

Results concerning body weight and body weight gain of Cobb chick's fed low crude protein diet supplemented with different levels of Moringa Oliefera Leaves meal (MOL) are shown in Table 3.

Data revealed that chicks fed low crude protein (LCP, 20 and 17\% during the starting and the finishing periods; negative control without supplementation, $T_{2}$ ) diet had the lowest body weight (BW) during the overall experimental period ( $35 \mathrm{~d}$ ). At 3 weeks of age, chicks fed MOL at levels of 0.25 or $0.50 \%$ to broiler diets have the highest body weight being 789.18 and $792.34 \mathrm{~g}$, respectively compared to the other treatments (positive control, negative control $+0.75 \% \mathrm{MOL}$ and the negative control without supplementation), being $770.04,745.12$ and $706.29 \mathrm{~g}$, respectively.

The same trend was noticed at 5 wks. (marketing age), chicks fed 0.25 or $0.50 \%$ MOL gained the highest body weight, 1959.65 and $1953.30 \mathrm{~g}$ in comparison with the other groups; positive control, negative control $+0.75 \% \mathrm{MOL}$ and the negative control without supplementation being 1801.21, 1779.39 and $1774.84 \mathrm{~g}$, respectively, which showed equally final body weight.

Also, body weight gain (BWG) was significantly affected by dietary low crude protein diet with the supplementation of Moringa Oleifera leaves meal (MOL) $(0,0.25,0.50$ and $0.75 \%)$. Average weight gains from $0-3$ and $0-5$ wks of chicks fed 0.25 and $0.50 \%$ of MOL showed the best gain, being $749.18,752.34 \mathrm{~g}$ and 1919.65 , $1913.29 \mathrm{~g}$, respectively compared to the other treatments, which recorded 730.04 , 705.12, 666.29g and 1761.39, 1729.39, $1734.83 \mathrm{~g}$ in groups fed the positive control, negative control $+0.75 \% \mathrm{MOL}$ and negative control without supplementation, respectively.

These results are in agreement with the results of Donkoe et al. (2013) who reported that body weight gain increased with increasing the levels of $\mathrm{MOL}$ at all ages $(0-14,14-35$ and $0-35 d)$. Also, Teteh et al. (2013), El-Tazi and Tibin (2014) who found that body weight gain was significantly improved with the inclusion of MOL at $5 \%$ in the broiler diet as compared to other treatment diets and Hassan et al. (2016) found that broilers fed MOL significantly increased weight gain compared to those fed un supplemented diets. 
Table 3: Body weight and body weight gain (g) of Cobb chicks fed low crude protein diets supplemented with different levels of Moringa Oliefera Leaves, MOL (Means $\pm \mathrm{S}$. E).

\begin{tabular}{ccccc}
\hline & \multicolumn{2}{c}{ Body weight $(\mathrm{g})$} & \multicolumn{2}{c}{ Body weight gain $(\mathrm{g})$} \\
\cline { 2 - 5 } Treatments $^{1}$ & 3 weeks & 5 weeks & 3 weeks & 5 weeks \\
\cline { 2 - 5 } & $770.04^{\mathrm{b}} \pm 2.50$ & $1801.21^{\mathrm{b}} \pm 13.83$ & $730.04^{\mathrm{b}} \pm 2.50$ & $1761.21^{\mathrm{b}, 2, \mathrm{e}} \pm$ \\
$\mathrm{T}_{1}$ & $706.29^{\mathrm{d}} \pm 2.83$ & $1774.84^{\mathrm{b}} \pm 7.99$ & $666.29^{\mathrm{d}} \pm 2.83$ & $1734.83^{\mathrm{b}} \pm 7.99$ \\
$\mathrm{~T}_{2}$ & $789.18^{\mathrm{a}} \pm 2.73$ & $1959.65^{\mathrm{a}} \pm 9.98$ & $749.18^{\mathrm{a}} \pm 2.73$ & $1919.65^{\mathrm{a}} \pm 9.98$ \\
$\mathrm{~T}_{3}$ & $792.34^{\mathrm{a}} \pm 3.06$ & $1953.30^{\mathrm{a}} \pm 10.40$ & $752.34^{\mathrm{a}} \pm 3.06$ & $1913.29^{\mathrm{a}} \pm 10.40$ \\
$\mathrm{~T}_{4}$ & $745.12^{\mathrm{c}} \pm 6.34$ & $1779.39^{\mathrm{b}} \pm 14.92$ & $705.12^{\mathrm{c}} \pm 6.34$ & $1729.39^{\mathrm{b}} \pm 14.91$ \\
$\mathrm{~T}_{5}$ & $*$ & $*$ & $*$ & $*$ \\
\hline Sig & \multirow{2}{*}{${ }$} & & $*$ & $*$
\end{tabular}

${ }^{1} \mathrm{~T}_{1}$ : Basal diet (Positive control), $\mathrm{T}_{2}$ : Negative control, $\mathrm{T}_{3}$ : Negative control $+0.25 \% \mathrm{MOL} / \mathrm{kg}$ diet, $\mathrm{T}_{4}$ : Negative control $+0.50 \% \mathrm{MOL} / \mathrm{kg}$ diet, $\mathrm{T}_{5}$ : Negative control $+0.75 \% \mathrm{MOL}$.

${ }^{2}$ means \pm S.E. of 3 replicates/ treatment.

${ }^{3}$ a,b,c.........etc: Means within the same column with different superscripts are significantly different $(P<0.05)$.

\section{b. Feed intake, feed conversion ratio and performance index:}

Data of daily feed intake (FI) of Cobb chicks fed low crude protein diet supplemented with different levels of Moringa Oliefera leaves (MOL) meals is summarized in Table (4). Concerning feed intake during $0-3$ and $0-5$ wks. of age, chicks fed LCP diet supplemented with 0.25 or $0.50 \%$ MOL was significantly increased, being $61.63,61.85$ and 96.15 , $96.24 \mathrm{~g}$, respectively in comparison with chicks fed the positive control diet (normal protein) or those fed low crude protein diet with or without Moringa Oliefera leaves.

The enhancement of feed intake of chicks fed MOL diets is agreement with Melesse et al. (2013) found that chicks fed diets containing $5 \% \mathrm{MOL}$ significantly consumed more feed than the control diet.

Data of feed conversion ratio (FCR) was illustrated in Table (4). At three weeks of age, FCR of groups fed LCP diet supplemented with different levels of MOL $0.25,0.50$ and $0.75 \%$ MOL $(1.73,1.73$ and 1.74) had similar to those fed normal protein diet (1.70).

At the marketing age (35 d) chicks fed low crude protein diets supplemented with MOL at levels of $0.25 \%\left(T_{3}\right)$ or $0.50 \%$ $\left(T_{4}\right)$ were more efficient in converting feed into meat than the other groups $\left(T_{1}\right.$, $T_{2}$ and $T_{5}$ ), being 1.75 and 1.76 vs. 1.82, 1.84 and 1.82 , respectively.

These findings are in agreement with El - Tazi and Tibin (2014) who noted that feed intake and feed conversion ratio were improved with the supplementation of Moringa Oliefera leaves at the level of $\mathbf{5 \%}$ in broiler diets.

The same trend was noticed in performance index (Table 4) throughout different periods $(0-3)$ and $(0-5)$ wks. which showed that chicks fed low crude protein diet supplemented with 0.25 or $0.50 \% \mathrm{MOL}$ have the best performance index $(45.60,45.78)$ and $(112,111)$ compared to the other groups. 
Table 4: Daily feed intake (g), feed conversion ratio ( $g$ feed $/ \mathrm{g}$ gain) and performance index of Cobb chicks fed low crude protein diets supplemented with different levels of Moringa Oliefera Leaves, MOL (Means $\pm S$. E).

\begin{tabular}{|c|c|c|c|c|c|c|}
\hline \multirow{2}{*}{ Treatments $^{1}$} & \multicolumn{2}{|c|}{ Feed intake (g) } & \multicolumn{2}{|c|}{$\begin{array}{l}\text { Feed conversion ratio } \\
\text { (FCR, g feed / g gain ) }\end{array}$} & \multicolumn{2}{|c|}{$\begin{array}{l}\text { Performance } \\
\text { Index (PI, \%) }\end{array}$} \\
\hline & 3 weeks & 5 weeks & 3 weeks & 5 weeks & 3 weeks & 5 weeks \\
\hline $\mathbf{T}_{1}$ & $\begin{array}{c}59.26^{\mathrm{b}} \pm \\
0.44\end{array}$ & $\begin{array}{c}91.35^{b} \pm \\
0.18\end{array}$ & $\begin{array}{c}1.70^{b} \pm \\
0.01\end{array}$ & $\begin{array}{c}1.82^{a} \pm \\
0.02\end{array}$ & $\begin{array}{c}45.29^{a} \pm \\
0.41\end{array}$ & $\begin{array}{c}98.90^{\mathrm{b}, 2,3} \\
\pm 2.26\end{array}$ \\
\hline$T_{2}$ & $\begin{array}{c}57.03^{c} \pm \\
0.26\end{array}$ & $\begin{array}{c}91.26^{b} \pm \\
0.28\end{array}$ & $\begin{array}{c}1.80^{\mathrm{a}} \pm \\
0.01\end{array}$ & $\begin{array}{c}1.84^{\mathrm{a}} \pm \\
0.02\end{array}$ & $\begin{array}{c}39.22^{c} \pm \\
0.25\end{array}$ & $\begin{array}{c}96.20^{c} \pm \\
1.21\end{array}$ \\
\hline$T_{3}$ & $\begin{array}{c}61.63^{\mathrm{a}} \pm \\
0.31\end{array}$ & $\begin{array}{c}96.15^{\mathrm{a}} \pm \\
0.24\end{array}$ & $\begin{array}{c}1.73^{b} \pm \\
0.01\end{array}$ & $\begin{array}{c}1.75^{b} \pm \\
0.02\end{array}$ & $\begin{array}{c}45.60^{\mathrm{a}} \pm \\
0.17\end{array}$ & $\begin{array}{c}112.00^{\mathrm{a}} \pm \\
1.82\end{array}$ \\
\hline $\mathbf{T}_{4}$ & $\begin{array}{c}61.85^{\mathrm{a}} \pm \\
0.31\end{array}$ & $\begin{array}{c}96.24^{\mathrm{a}} \pm \\
0.11\end{array}$ & $\begin{array}{c}1.73^{b} \pm \\
0.01\end{array}$ & $\begin{array}{c}1.76^{b} \pm \\
0.02\end{array}$ & $\begin{array}{c}45.78^{a} \pm \\
0.22\end{array}$ & $\begin{array}{c}111.00^{\mathrm{a}} \pm \\
1.88\end{array}$ \\
\hline$T_{5}$ & $\begin{array}{c}58.51^{b} \pm \\
0.53\end{array}$ & $\begin{array}{c}90.16^{b} \pm \\
0.31\end{array}$ & $\begin{array}{l}1.74^{\mathrm{b}} \pm \\
0.01\end{array}$ & $\begin{array}{c}1.82^{\mathrm{a}} \pm \\
0.02\end{array}$ & $\begin{array}{c}42.82^{b} \pm \\
0.54\end{array}$ & $\begin{array}{c}96.74^{b} \pm \\
1.92\end{array}$ \\
\hline Sig & * & * & * & * & * & * \\
\hline
\end{tabular}

${ }^{1} \mathrm{~T}_{1}$ : Basal diet (Positive control), $\mathrm{T}_{2}$ : Negative control, $\mathrm{T}_{3}$ : Negative control $+0.25 \% \mathrm{MOL} / \mathrm{kg}$ diet, $\mathrm{T}_{4}$ : Negative control $+0.50 \% \mathrm{MOL} / \mathrm{kg}$ diet, $\mathrm{T}_{5}$ : Negative control $+0.75 \% \mathrm{MOL}$.

${ }^{2}$ means \pm S.E. of 3 replicates/ treatment.

3a,b,c........etc: Means within the same column with different superscripts are significantly different $(P<0.05)$.

${ }^{4}$ Performance Index $(\mathrm{PI})=$ (live body weight $(\mathrm{kg}) \times 100 /$ feed conversion.

The improvement in BWG and FCR may be due to the improvement in CP digestibility and the nutrient utilization as a result of the presence of flavonoids which react as antibacterial and antioxidant. Also, the improvement may be due to the Moringa beneficial effect on the microbial environment in the gut which might enhance digestion, absorption and utilization of nutrients

2. Effect of dietary low crude protein diet supplemented with different levels of Moringa Oliefera Leaves meal (MOL) on Cobb chicks on carcass characteristics:

The obtained results (Table 5) showed that low crude protein diet supplemented with Moringa Oliefera leaves significantly affect some carcass traits. Chicks fed low crude protein diet supplemented with 0.25 or $0.50 \% \mathrm{MOL}$ have the highest carcass weight (1753 and $1738 g$ ) with no significant differences between them compared to 1603,1546 and $1555 \mathrm{~g}$ in groups fed normal crude protein diet $\left(\mathrm{T}_{1}\right)$ and negative crude protein without supplementation or with $0.75 \%$ MOL. Neither CP levels nor MOL levels had significant effect on dressing or gizzard percentages.

These results are in agreement with Ayssiwede et al. (2011) who reported that there were no significant differences among treatments fed the inclusion of Moringa Oliefera leaves meal.

Also, Nkukwana et al. (2014) and Hassan et al. (2016) found that addition of MOL meal at levels of $0.1-2.5 \%$ to broiler diets have no significant effects on carcass weight, dressing percentage and the relative weight of liver, gizzard, heart and spleen. 


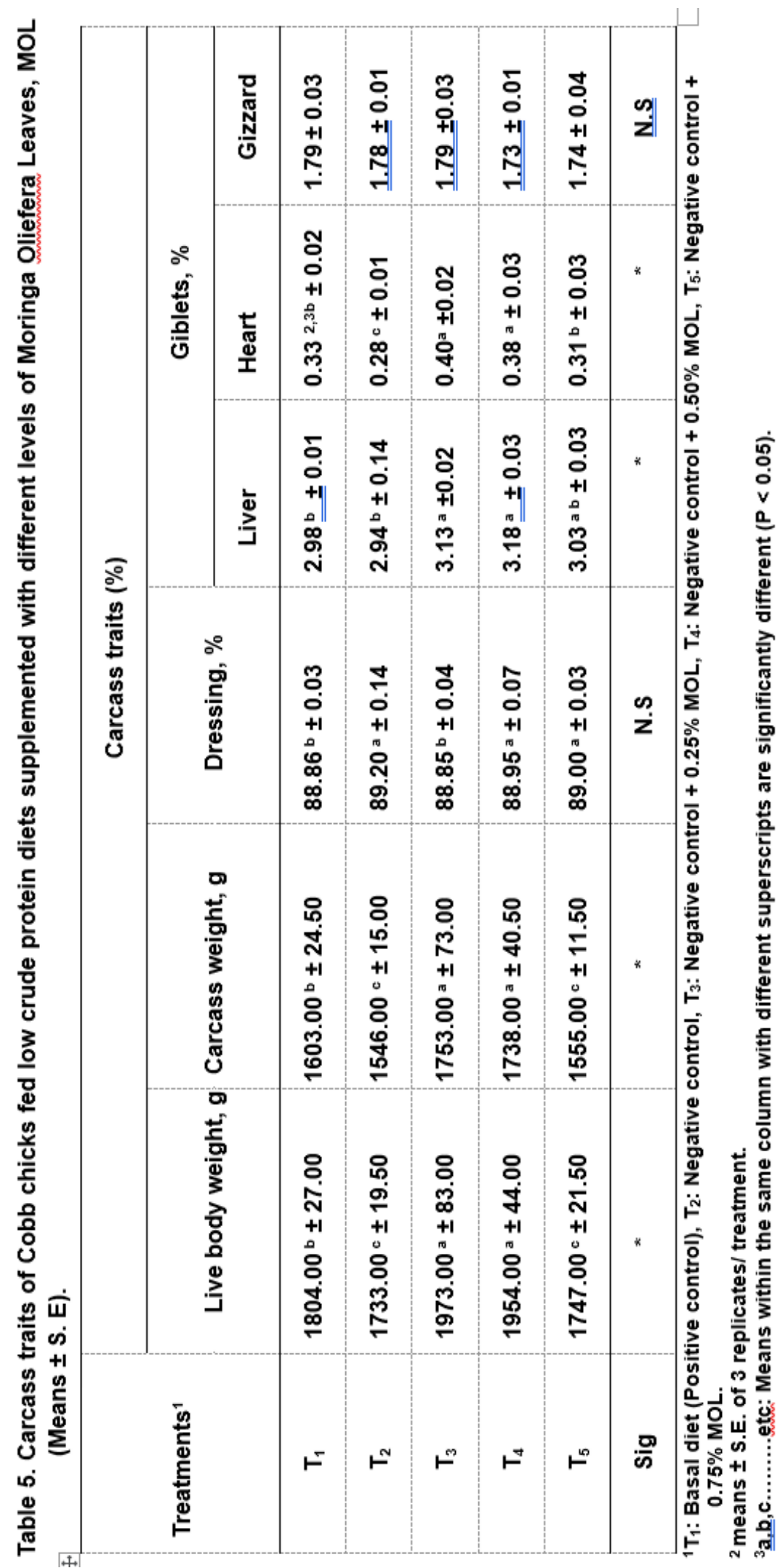


3. Effect of dietary low crude protein diet supplemented with different levels of Moringa Oliefera Leaves meal (MOLM) on some serum blood biochemical parameters of Cobb chicks:

Serum total protein levels was significantly increased as MOLM increased $(0.25,0.50$ and $0.75 \%$ Table 6$)$. The highest level was recorded in chicks fed $0.75 \%$ MOL supplemented to low crude protein diet with no significant differences between all MOL levels (4.73, 4.41 and $4.49 \mathrm{gl} \mathrm{dl}$ ), respectively, compared to the negative control diet (un supplemented), being 4.10 and $4.41 \mathrm{~g} / \mathrm{dl}$, respectively, in chicks fed the normal protein diet.

Serum albumin was insignificantly affected by the supplementation. However, serum glucose level was also higher with no significant differences in groups fed low crude protein diet supplemented with $0.25 \%\left(T_{3}\right)$ or $0.50 \%$ $\left(\mathrm{T}_{4}\right) \mathrm{g}$ Moringa leaves powder, being $\mathbf{1 1 . 4 1}$ and $12.56 \mathrm{mg} / \mathrm{dl}$, respectively, and significantly differ with the higher level of MOL $(14.02 \mathrm{mg} / \mathrm{dl})$ which recorded the highest level compared to the lowest levels in groups fed the normal protein diet $(10.32 \mathrm{mgl} \mathrm{dl})$ and those fed low crude protein diet without supplementation $(9.87 \mathrm{mg} / \mathrm{dl})$.

Total serum protein is a reflection of the metabolic activities related to protein synthesis or protein degradation (Hassan et al., 2016). Increased total protein in chicks fed MOL diet may reflect a more intensive metabolism of protein in the chicken's organ (Melesse et al., 2013) or may be due to high content of Moringa from antioxidant (Onu and Aniebo, 2011; El-Wardany et al., 2012 and Asante et al., 2014) which increases total blood protein by decreasing corticosterone secretion which could limit protein catabolism under heat stress conditions.

The results of serum aminotransferase activity (AST and ALT) of chicks fed low crude protein diet supplemented with different levels of Moringa Oliefera leaves showed that aspartic aminotransferase (AST) level was significantly decreased $(P \geq 0.05)$ by the supplementation levels $(0.25,0.50$ or $0.75 \%$ of broiler diet), being 205, 202 and $210 \mathrm{U} / \mathrm{L}$, respectively with no significant differences between them compared to those fed normal protein diet (228 $\mathrm{U} / \mathrm{L}$ ) or chicks fed low crude protein diet without MOL (232 UI L) which recorded the highest level.

Alanine aminotransferase enzyme (ALT) did not significantly affected by MOL supplementation (11.23, 11.17 and $11.50 \mathrm{U} / \mathrm{L})$, respectively in groups fed $0.25,0.50$ or $0.75 \%$ compared to the normal protein diet (11.85 U/ L), but significantly differ with those fed low crude protein diet without supplementation (12.94 U/ L).

These results are in agreement with those of Hassan et al. (2016) and Sherwin (2003) who noted that liver released its content of AST and ALT enzymes when it damaged. Elevation of serum AST and ALT can occur with states of altered hepatocellular membrane permeability either due to circulatory hypoxia, exposure to toxins and toxemia and increased activities of AST and ALT were associated with liver and intestinal damage (Rani et al., 2011).

From Table (6) data revealed that total cholesterol (82.03 and $86.95 \mathrm{mg} / \mathrm{dl}$ ) and triglycerides (80.08 and $81.95 \mathrm{mg} / \mathrm{dl}$ ) were significantly decreased $(P \geq 0.05)$ with increasing the levels of MOL (0.25 and $0.50 \%$ ) except for chicks fed the highest level of Moringa leaves powder $(0.75 \%)$ recorded the highest levels of both total cholesterol and triglycerides 


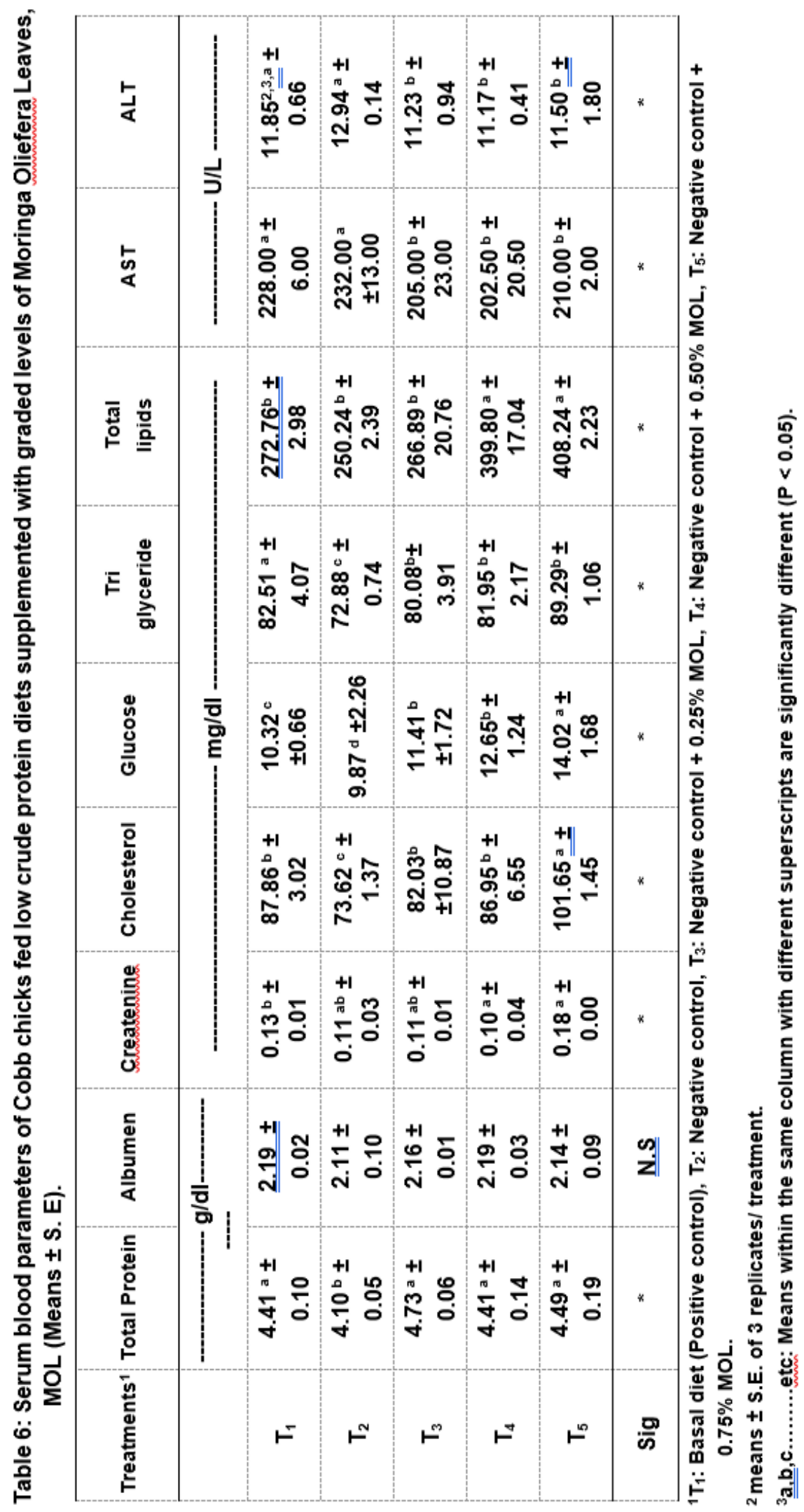


being 101.65 and $89.29 \mathrm{mg} / \mathrm{dl}$, respectively compared to the positive control diet which recorded 87.86 and $82.51 \mathrm{mg} / \mathrm{dl}$, for total cholesterol and triglycerides, respectively.

The reduction of total cholesterol and triglycerides levels in broiler blood serum fed diet containing MOL is in agreement with the findings of Zanu et al. (2011) who reported hypercholesterolemia effect of MOL in broiler as Moringa contain high amount of polyphenols (Moyo et al., 2012) flavonoids, alkaloids and phenolic compound possess the hypocholesterolaemic and immunity enhances effect.

The reverse effect was noticed with serum createnine which showed significantly reduction with increasing Moringa leaves powder levels up to $0.50 \%$. These results are in agreement with Hussein and Jassim (2019) and Divya et al. (2014) who noted that createnine is a west molecule that is generated from protein metabolism. Reduction in createnine formation indicated retarded catabolism rate in broilers and perhaps response for nonsignificant reduction in chick's body weight.

4. Effect of dietary low crude protein diet supplemented with different levels of Moringa Oliefera Leaves Meal (MOL) on some intestinal morphological parameters of Cobb chicks:

The results of intestinal morphological parameters are presented in Table 7 and Figures 1, 2, 3, 4 and 5. Results showed that villi height, width and height: width ratios were increased by the supplementation of different levels of MOL $(0.25$ and $0.50 \%$ of low crude protein broiler diet) but not significant except in duodenum villi width and in the ration between height and width.
The highest duodenum villi height and width was noticed in chicks fed the lowest MOL level (0.25\%), being 2032 and $246 \mu \mathrm{m}$ compared to the other treatments. Reversible effect was noticed with the highest level of MOLM $(0.75 \%)$ which recorded the lowest villi height and width in all intestinal sections except in ilium width which recorded the highest (207 $\mu \mathrm{m})$ compared to the other segments.

The increased in chicks body weight is coupled with the length of duodenum and jejunum villi. In duodenum and jejunum, this increase in villi height get translated into highest villus surface area observed in 0.25 and $0.50 \%$ groups. These observations suggest improved possibility of nutrient absorption and therefor improved body weight. Our findings are supported by Tesfaye et al. (2013); Nkukwana et al. (2014 and Kkan et al. (2017).

5. Effect of dietary low crude protein diet supplemented with different levels of Moringa Oliefera Leaves Meal (MOL) on economic efficiency ratio:

Results of feeding cost of the experimental diets are presented in Table (8). Through our inputs and outcomes for 5 weeks old of Cobb chicks fed different levels of MOLM $(0.25,0.50$ and $0.75 \%)$ in low crude protein diet ( 20 and $17 \%$ during starting and finishing periods). Results showed that feed cost/kg weight gain was increased with increasing level of Moringa Oliefera leaves meal. Chicks fed $0.25 \% \mathrm{MOL}$ had the highest net revenue $(27.85$ L.E.) and relative economic efficiency (130\%) between all MOL levels and it decreased up to this level. Also, Europeans efficiency index was significantly increased up to $0.50 \% \mathrm{MOL}$, being 313 and $310 \%$ in chicks fed 0.25 and $0.50 \%$ and decreased after that means that MOL should not be used to up to 0.25 or $0.50 \%$ in low crude protein diet under our experimental conditions. 


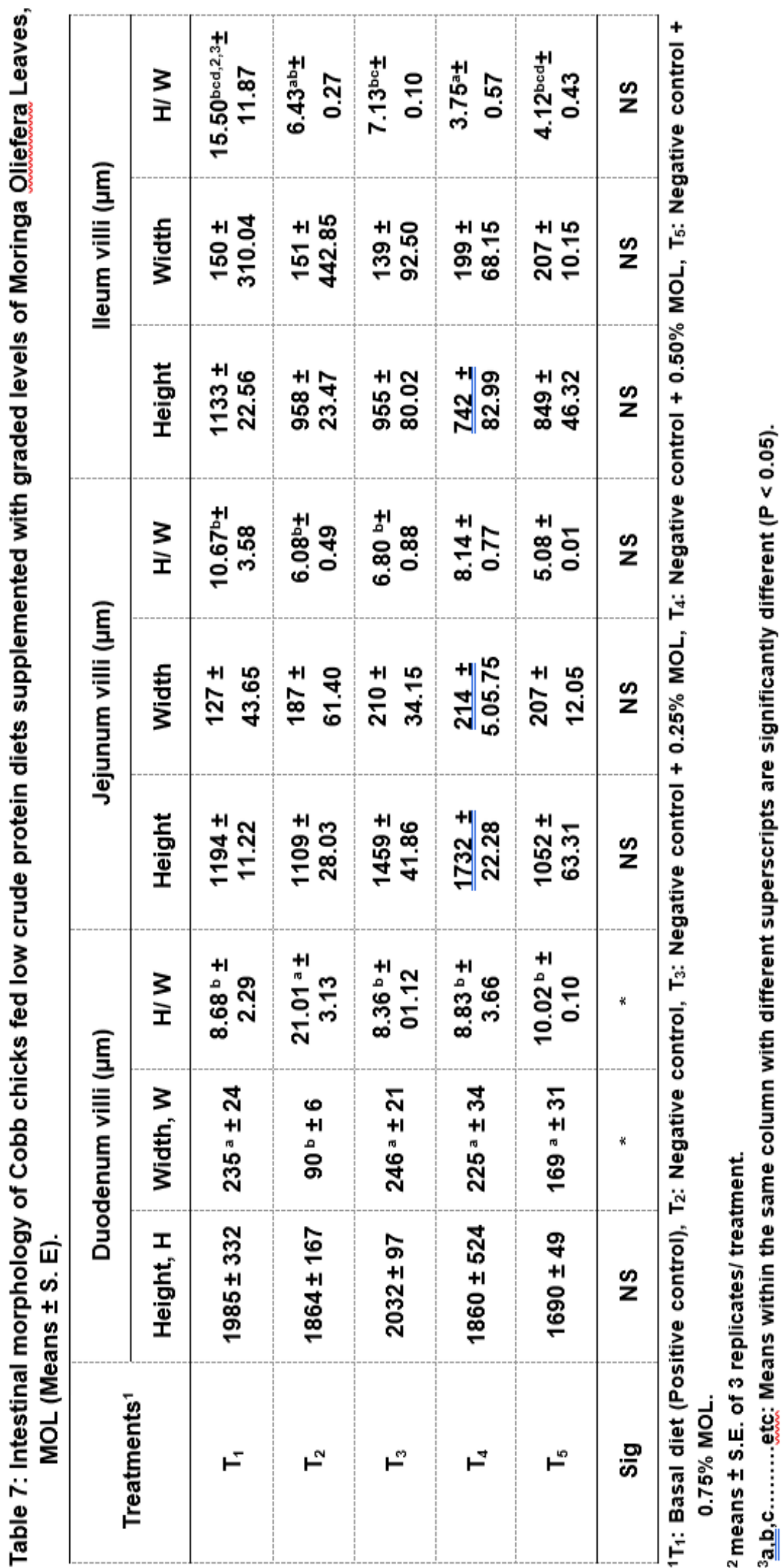




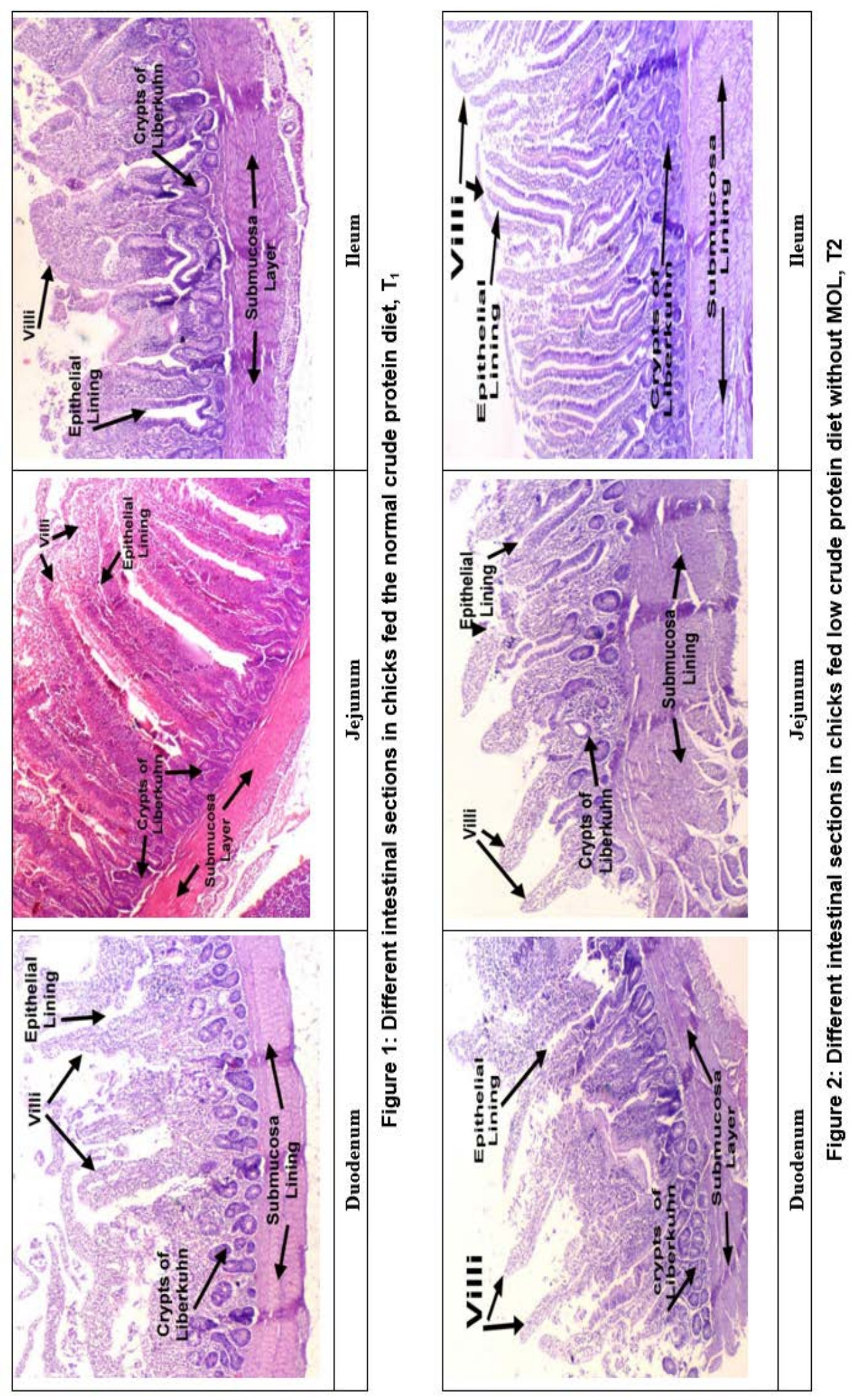



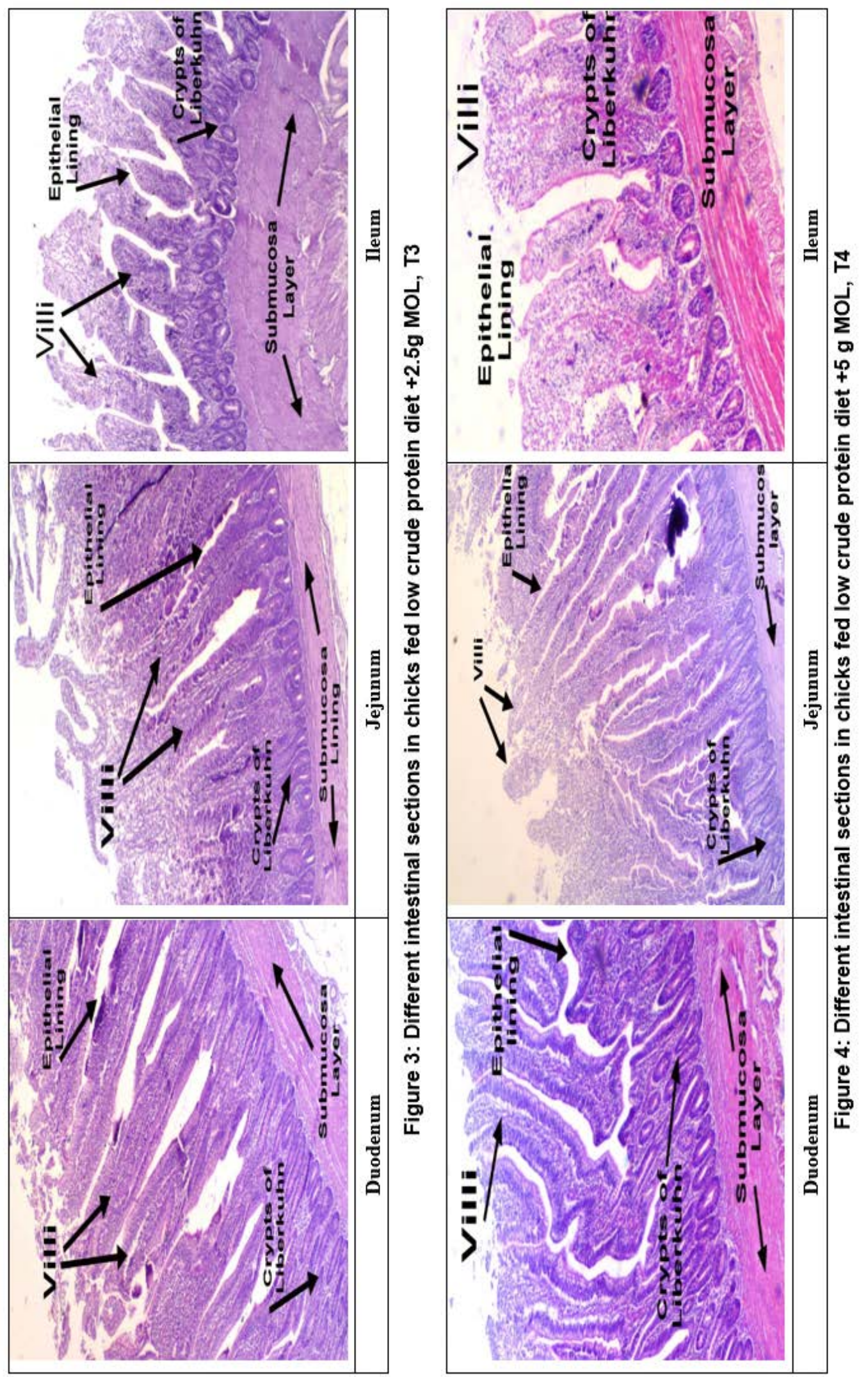


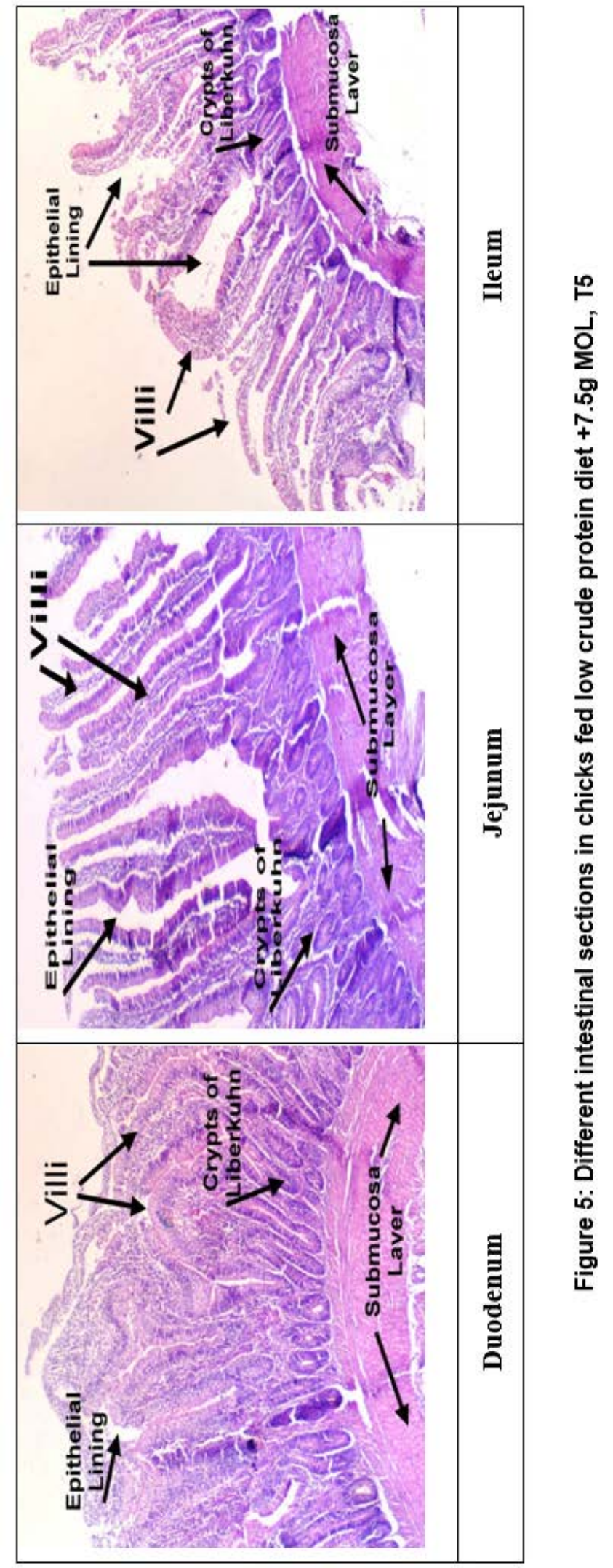




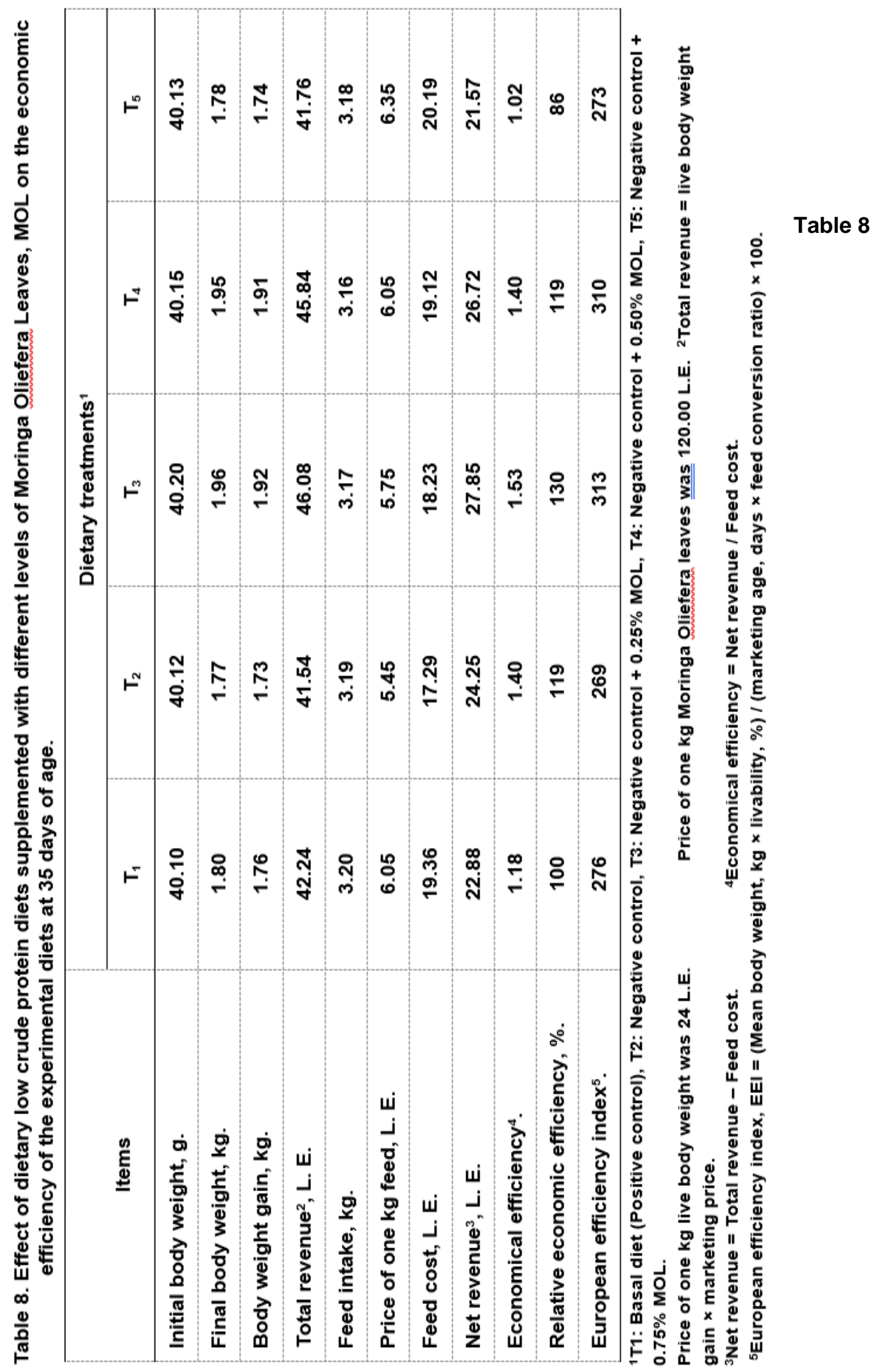




\section{CONCLUSION}

The obtained results in the present investigation are encouraging and indicated that supplementation of $0.25 \%$ Moringa Oliefera Leaves, MOL can be used in broiler diets with low protein level to get heaviest weight, best feed conversion, performance index, due to an increase in small intestinal absorption and activity. This, in turn, resulted in an increase in European efficiency index and economic efficiency.

\section{REFERENCES}

Abbas, T. E. (2013). The use of Moringa Oleifera in poultry diet. Turkish $\mathbf{J}$. of Vet. And Anim. Sci., 37: 492 - 496.

Asante, W. J., I. L. Nasare, D. Tom-Dery, K. Ochire-Boadu and K. B.

Kentil (2014). Nutrient composition of Moringa Oleifera leaves from two agro ecological zone in Ghana. Afr. J. Plant Sci., 8: 65 - 71.

Ayssiwede, S. B., A. Dieng, H. Bello, C. A. A. M. Chrysostome and M. B. Hane (2011). Effects of Moringa Oleifera (Lam.) leaves meal incorporation in diets on growth performances, carcass characteristics and economics results of growing indigenous Senegal chickens. Pak. J. Nutr., 10: 1132 - 1145.

Divya, A. B. Mandal, A. Biswas, A.S. Yadav and A. K. Biswas (2014). Animal Nutrition and feed technology .14:349357.

Donkoe, A. M., R. L. K. Glover, D. Addae and K. A. Kubi (2013). Estimating the nutritional value of the leaves of Moringa Oleifera on poultry. Food Nutr. Sci., 4: 1077 - 1083.

Duncan, D. B. (1955). Multiple range and multiple F tests. Biometrics, 11:1- 42.

El-Tazi, S.M.A. and I. M. Tibin (2014). Performance and blood chemistry as affected by inclusion of Moringa
Oleifera leaves meal in broiler chicks diet. U. of K. J. Vet. Med. Anim. Pro., Vol. 5: 58-65.

El-Wardany, I., M. M. A. El-Moniary, A. A. Hemid, A. E. Gehad and A. Gouda (2012). The effect of early age heat conditioning and some feeding programs for heat stressed broiler chickens: 2- physiology responses. Egypt. J. Nutr. Feeds, 15: 265 - 277.

Esiegwu, A. C. (2019). The supplementary effect of Moringa Oleifera leaves water on performance and blood indices of finisher broilers. Direct Res. J. of Vet. Med. and anim. Sci., Vol. 4 (4): pp. 2732, ISSN: 4372- 2601.

FAO (1997). Human nutrition in the developing world. Latham M.C. FAO food and Nutr., 29.

FAO (2010). Poultry Meat and Eggs: Agribusiness Handbook. Director of Investment Centre Division, FAO, Rome, Italy, 77.

Geyra A., Z. Uni and D. Sklan (2001). Enterocyte dynamics and mucosal development in the post hatch chick. Poult. Sci. 80, 776 - 782.

Hassan, H. M. A., M. M. El-Moniary, Y. Hamouda, Eman F. El-Daly, A. W. Youssef and N. A. Abd El- Azeem (2016). Effect of different levels of moringa oleifera leaves meal on productive performance, carcass characteristics and some blood parameters of broiler chicks reared under heat stress conditions. Asian J. of Anim. and Vet. Advances. ISSN 1683-9919

Dol: 10.3923/ajava.2016.60.66.

Heady, E. O. and H. R. Jensen (1954). Farm Management Economics. Pentice - Hall Inc. Englewood Cliffs, N.J., USA.

Hussein, H. H. and J. M. Jassim (2019). The influence of moringa oleifera leaves meal and their aqueous ethanolic leaves extracts on growth 
performance and blood parameters of broiler chickens. Plants archives Voi. 19, supplement 2, 2019pp 1841-1848.

Khan, I., H. Zaneb, S. Masood, M. S. Yousaf, H. F. Rehman and H. Rehman (2017). Effect of moringa oleifera leaves powder supplementation on growth performance and intestinal morphology in broiler chickens. J. of Anim. Physio. and Anim. Nutr. Volume 101, ISSUE S1 Pages 114-121.

Melesse, A., H. Steingass, J. Boguhu and M. Rodehutscord (2013). In vitro fermentation characteristics and effective utilizable crude protein in leaves and green pode of Moringa stenopetala and Moringa Oleifera cultivated at low and mid - altitudes. J. Anim. Physiol. Anim. Nutr., 97: 537 $-546$.

Moyo, B., S. Oyedemi, P. J. Masika, V. Muchenje (2012). Polyphenolic content and antioxidant properties of Moringa oleifera leaves extracts and enzymatic activity of liver from goats supplemented with Moringa oleifera leaves/sunflower seed cake. Meat Science 91: $441-447$

Nihad, A. A. A., F. M. A. Hanaa, S. A. Sherein, A. A. Fatma and M. Farid (2016). Moringa Oleifera leaves in broiler diets: Effect on chicken performance and health. Food Sci. and Quality Management. Vol.58 ISSN 224-6088.

Nkukwana, T. T., V. Muchenje, E. Pieterse, P. J. Masika, T. P. Mabusela, L. C. Hoffman and K. Dzama (2014). Effect of Moringa Oleifera leaves meal on growth performance, apparent digestibility, digestive organ size and carcass yield in broiler chickens. Livestock Sci., 161; 139 - 146.

North, M. O. (1981). Commercial chicken production manual. $3^{\text {rd }}$ Ed., The AVI, Publishing Co. Inc., West-port, Connecticut, U. S. A.
NRC, (1994). Nutrient requirements of poultry. 9th rev. ed. Washington (DC): National Academy Press.

Onu, P. and A. Aniebo (2011). Influence of Moringa Oleifera leaves meal on the performance and blood chemistry of starter broilers. Int. J. Food Agri. Vet. Sci., 1(1):38-44.

Rani, M. P., N. N. Ahmad, P. E. Prasad and C. S. Latha (2011). Hematological and biochemical changes of stunting syndrome in broiler chicken. Vet. World, 4: 124 - 125.

Sagarpa (Secretaría de Agricultura, Ganadería, Desarrollo Rural, Pesca y Alimentación) (2017). Comunicado de prensa, La Paz, Baja California Sur, 13 de octubre de 2017. Disponible en la Web:

http://www.sagarpa.gob.mx/Delegacio nes/bajacaliforni

asur/boletines/2017/octubre/Document s/2017BS336.pdf

Sherwin, J. E., (2003). Liver function. In: clinical chemistry: theory analysis, correlation, Kaplan, L. A., A. J. Pesce and S. C. Kazmierczak (Eds.). $4^{\text {th }}$ Edn., Chapter 27, Elsevier Sci., St. Louis, MO., USA., ISBN - 13: PP: 492 - 506.

Snedecor, W. G. and G. W. Cochran (1982). Statistical methods. (6 ${ }^{\text {th }}$ ed.). iowa State College Press. Iowa, USA.

Sodamade, A., O. S. Bolaji and O. 0 . Adeboye (2013). Proximate analysis, mineral contents and functional properties of oringa oleifera leaves protein concenterates. Journal of Applied Chemistry (IOSR - JAC). Volume 4, Issue 6.

Soltan, M. E. and Z. Kusainova (2012). Performance of broiler chickens in different farming with different feed conversion under Egyptian conditions. Minufiya J. Agric. Res. V., 37 No. 5 (1): 1155 - 1159.

SPSS (2011). SPSS 11.0 for Windows. SPSS Inc., Chicago. Standardization 
ministration of china. 2005. National feed Industry Standards for Enzyme Assays in china.

Tesfaye, E., G. Animut, M. Urge and T. Dessie (2013). Moringa olifera leaves meal as an alternative protein feed ingredient in broiler ration. Int $\mathrm{J}$ Poult Sci 12 (5): 289-297.

Teteh, A., E. Lawson, K. Tona, E. Decuypere and M. Gbeassor (2013). Moringa Oleifera leave: hydro alcoholic extract and effects on growth performance of broilers. Int. J. Poult. Sci., 12: 401 - 405.

Udedibie, A. B. and C. O. Asoluka (2008). Effect of $5 \mathrm{~h}$ welting of sun dried cassava tuber meal on the HCN content and dieting value of the meal for young broiler chicks. J Anim Produc 1: 25-31.

Ugwuowo, LC. , C. I. Ezeano, A.D. Olabode and C. Anikwue (2019). Performance and cost evaluation of broilers fed diets containing soyabean meal replaced with varying levels of Moringa Oleifera leaves meal. J.of Anim. Res. and Nutri. Vol (4); ISSN 2572-5459.

Zanu, H. K., P. Asiedu, M. Tampuori, M. Abada and I. Asante (2011). Possibilities of using moringa (Moringa oleifera) leaves meal as a partial substitution for fishmeal in broiler chicken diets. Online Journal of Animal and Feed Research 2(1): 7075. 
الأداء الإنتاجى والتغير الهستولوجى لكتاكيت التسمين المغذاة على علائق منخفضة البروتين بإضافة مسحوق أوراق المورينجا

منال كمال أبو النجا، عاطف محمد حسن أبو عاشور، سيد عبد الفتاح عبد الرحمن،

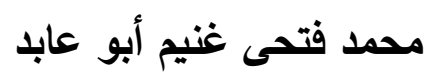

قسم إنتاج الدواجن والأسماك، كلية الزراعة، جامعة المنوفية، شبين الكوم، مصر

الملخص العربي

أجريت هذه التجربة لاراسة تأثير إضافة مسحوق أولق المورينجا الجافة في علائق كتاكيت التسمين المنخفضة البروتين على كل من كفاءة النمو, صفات الذبيحة, بعض مكونات الام، بعض التغيرات الهستولوجية فى الأمعاء والكفاءة التهات

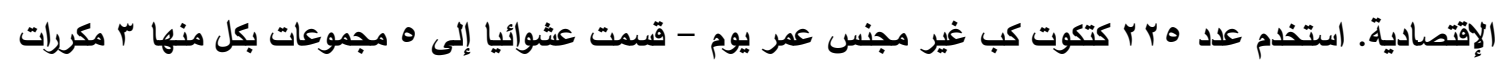

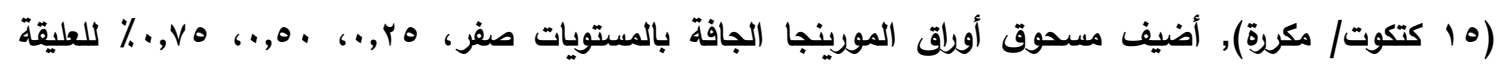

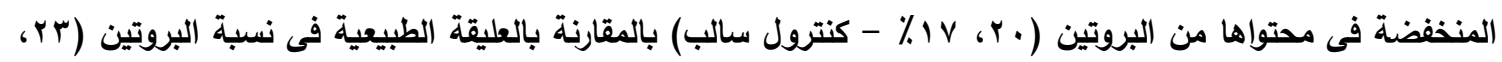

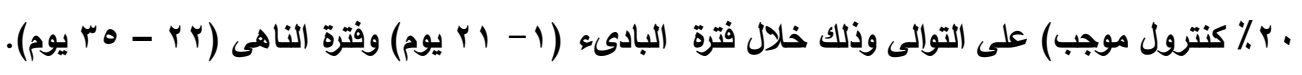

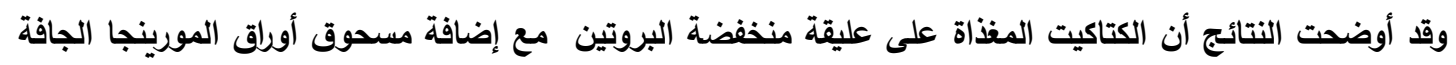

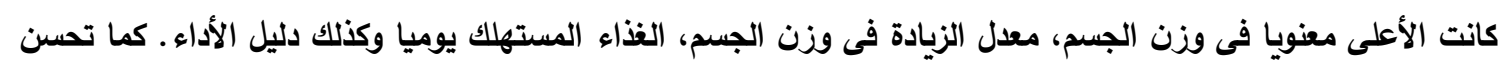

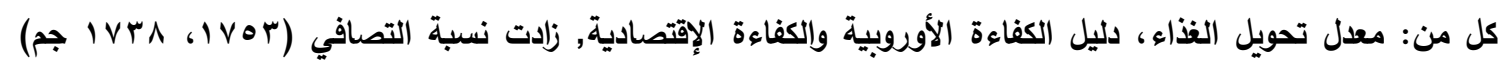

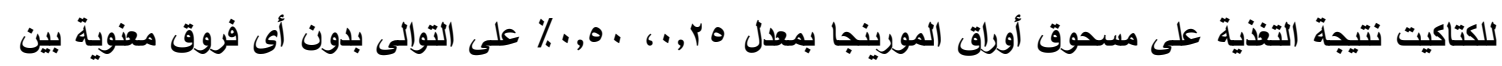
باقى المستويات.

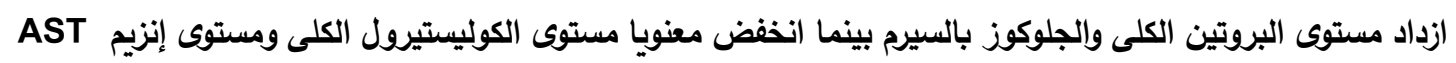

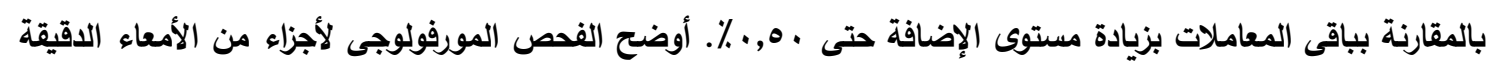

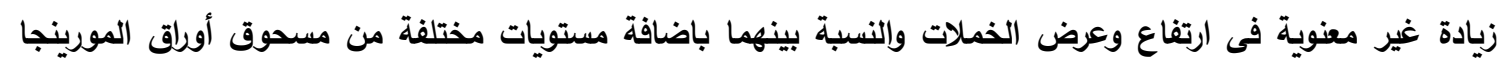

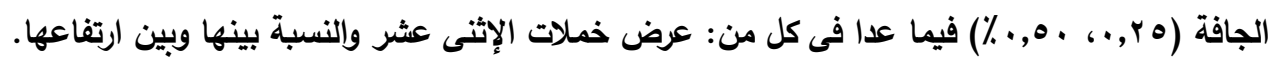

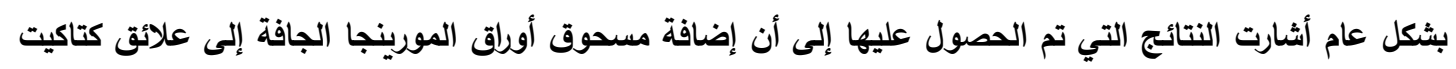

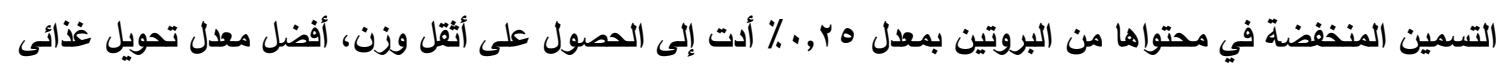

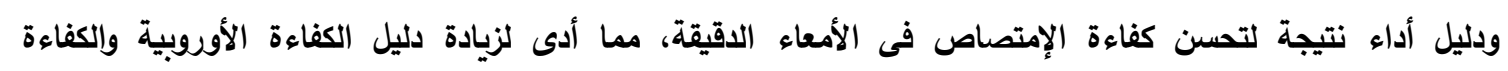
الإقتصادية تحت ظروف التجربة.

أسماء السادة المحكمين

كلية الزراعة - جامعة سوهاج أ.د/ طلعت مصطفى الثيخ

كلية الزراعة - جامعة المنوفية

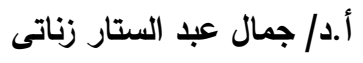


Manal K. Abou El - Naga, et al., 